\title{
STUDI SANITASI PENGELOLAAN LINEN DI RUMAH SAKIT PKU MUHAMMADIYAH GOMBONG KABUPATEN KEBUMEN TAHUN 2015
}

\author{
Yoga Dwi Prasetyo ${ }^{1)}$, Marsum ${ }^{2)}$ \\ Jurusan Kesehatan Lingkungan, Politeknik Kesehatan Kemenkes Semarang, \\ Jl. Raya Baturaden KM 12 Purwokerto, Jawa Tengah, Indonesia
}

\begin{abstract}
Abstrak
Rumah sakit juga merupakan pusat pelatihan bagi tenaga kesehatan dan pusat penelitian medik. Tujuan Penelitian ini adalah untuk mengetahui tingkat sanitasi pengelolaan linen di Rumah Sakit Pelayanan Kesehatan Umum (PKU) Muhammadiyah Gombong Kabupaten Kebumen. Jenis penelitian ini adalah deskriptif yaitu dengan cara membandingkan hasil penenlitian yang dilakukan dengan teori dan peraturan yang berlaku yaitu KepMenKes RI Nomor 1204/MenKes/SK/X/2004 tentang persyaratan Kesehatan Lingkungan Rumah Sakit. Data yang diperoleh dikumpulkan dengan wawancara dan observasi, pengukuranya menggunakan checklist kuesioner dan pengukuran angka kuman.Tingkat sanitasi pengelolaan linen di Rumah Sakit PKU Muhammadiyah Gombong Kabupaten Kebumen termasuk dalam kategori memenuhi syarat dengan nilai 69,61\%. Hasil pemeriksaan mikrobiologi spora spesies Bacillus sp. pada linen kotor ruang rawat inap (7482 cfu/inc $\left.{ }^{2}\right)$, linen kotor ruang IBS (0 cfu/inc $\left.{ }^{2}\right)$, linen bersih ruang rawat inap (2205,9 cfu/inc $\left.{ }^{2}\right)$ dan linen bersih ruang IBS $\left(0\right.$ cfu/inc $\left.{ }^{2}\right)$. Peneliti menyimpulkan proses pengelolaan linen di Rumah Sakit PKU Muhammadiyah Gombong Kabupaten Kebumen masih ada yang belum memenuhi syarat yaitu pengangkutan, penerimaan, dan pengangkutan linen bersih.
\end{abstract}

Kata Kunci : Pengelolaan, Sanitasi, Linen rumah sakit

\begin{abstract}
The hospital is also a training center for health workers and medical research centers. Purpose of this study was to determine the level of sanitation of linen at Public Health Service (PKU) Muhammadiyah Hospital Gombong Kebumen regency. This type of research is descriptive, by comparing the results penenlitian done with the theory and regulations that Kepmenkes No. 1204 / Menkes / SK / X / 2004 on requirements Environmental Health Hospital. The data obtained were collected by interviews and observations, measuring using a checklist questionnaire and measuring the numbers of germs. The level of sanitation of linen at PKU Muhammadiyah Hospital Gombong Kebumen regency included in the eligible category with a value of $69.61 \%$. Results of microbiological examination of spores of species Bacillus sp. the dirty linen of wards $\left(7482 \mathrm{cfu} / \mathrm{inc}^{2}\right)$, soiled linen room IBS $\left(0 \mathrm{cfu} / \mathrm{inc}^{2}\right)$, clean linen inpatient rooms (2205.9 cfu/inc $\left.{ }^{2}\right)$ and clean linen space IBS $\left(0\right.$ cfu/inc $\left.{ }^{2}\right)$. Researchers concluded linen management process in PKU Muhammadiyah Hospital Gombong Kebumen regency there are not eligible, namely transport, reception, and transporting clean linen.
\end{abstract}

Keywords : Managemen;, Sanitation; linen hospital

\section{PENDAhuluan}

Tujuan pembangunan kesehatan untuk Indonesia yang Lebih Sehat adalah meningkatnya SDM kesehatan yang merata dan bermutu serta manajemen kesehatan yang akuntabel, transparan berdayaguna dan berhasil guna untuk menetapkan desentralisasi kesehatan yang bertanggungjawab, meningkatnya pemberdayaan masyarakat, swasta dan masyarakat madani dalam pembangunan kesehatan melalui kerjasama nasional dan global serta meningkatnya pelayanan kesehatan yang merata, terjangkau, bermutu, dan berkeadilan, serta berbasis bukti; dengan pengutamaan pada upaya promotif dan preventif yang ditandai oleh masyarakatnya yang hidup sehat yang mandiri dan berkeadilan sesuai

1) Email : -

2) Email : marsumrahma@gmail.com dengan visi dari Departemen Kesehatan (Depkes RI, 2014).

Untuk mewujudkan derajat kesehatan yang optimal, pembangunan bidang kesehatan khususnya kesehatan lingkungan dengan upaya kesehatan yang semula dititikberatkan pada upaya penyembuhan penderita secara berangsur-angsur berkembang kearah keterpaduan upaya kesehatan yang menyeluruh. Oleh karena itu, pembangunan kesehatan yang menyangkut upaya peningkatan kesehatan (promotif), pencegahan penyakit (preventif), penyembuhan penyakit (kuratif), dan pemulihan kesehatan (rehabilitative) harus dilaksanakan secara menyeluruh, terpadu dan berkesinambungan, dan dilaksanakan bersama antara pemerintah dan masyarakat (UU RI, 1992). 
Rumah sakit adalah sarana pelayanan kesehatan, tempat berkumpulnya orang sakit maupun orang sehat, atau dapat menjadi tempat penularan penyakit serta memungkinkan terjadinya pencemaran lingkungan dan gangguan kesehatan. Oleh karena itu untuk menghindari risiko dan gangguan kesehatan maka perlu penyelenggaraan kesehatan lingkungan rumah sakit sesuai dengan persyaratan kesehatan (Kepmenkes RI, No. 1204/MENKES/SK/X/2004).

Upaya kesehatan lingkungan rumah sakit meliputi kegiatan-kegiatan yang kompleks sehingga memerlukan penanganan secara lintas program dan lintas sektor serta berdimensi multi disiplin, untuk itu diperlukan tenaga dan prasarana yang memadai dalam pengawasan kesehatan lingkungan rumah sakit (Depkes RI, 2004). Salah satu upaya penyehatan lingkungan di Rumah Sakit PKU Muhammadiyah Gombong adalah pengelolaan linen.

Linen adalah serat lena yang didapat dari sejenis alang-alang yang tumbuh didaerah sub tropis yang kemudian serat dipintal dan ditenun menjadi textile yang halus dan berdaya serap tinggi (Sapta Raharsa, dkk, 1997). Dampak jika pengelolaan linen tidak baik mempunyai resiko penularan penyakit infeksi dan juga terdapat beberapa resiko bahaya yang mempengaruhi situasi dan kondisi di rumah sakit.

Rumah Sakit PKU Muhammadiyah Gombong, Kebumen adalah Rumah Sakit dengan pelayanan pasien 24 jam dengan jenis pelayanan Rawat Inap, Rawat Jalan, Fasilitas Pelayanan Umum ( Masjid, ATM, Warseda ), Billing system, Pemulasan Jenasah, Home care, Ambulan Gawat Darurat dan telah melakukan MoU Pelayanan dengan pihak kesehatan yaitu : PT Askes, Jamkesmas, Jamsostek, Jasa Raharja, Asuransi Tafakul, DSM, PT KAI, Allianz, PLN dan Telkom.

Berdasarkan survey pendahuluan yang telah dilakukan, linen dari rawat inap tidak melewati sterilisasi, penyetrikaan tidak menggunakan mesin rol suhu $120^{\circ} \mathrm{C}$ dan pengelola linen masih ada yang tidak menggunakan alat pelindung diri (APD). Sehingga dapat terjadinya penyakit akibat kerja karena adanya kontak langsung antara linen terhadap petugas pengelola linen . Hal itu juga berhubungan dengan sanitasi pengelolaan linen yang masih kurang diperhatikan oleh bagian pengelolaan linen di Rumah Sakit PKU Muhammadiyah Gombong. Kasus infeksi yang didapat dalam rumah sakit terjadi dengan angka yang cukup tinggi. Misalnya di Amerika Serikat, ada 20.000 kematian setiap tahun akibat infeksi nosokomial. Di seluruh dunia, 10 persen pasien rawat inap di rumah sakit mengalami infeksi yang baru selama dirawat - 1,4 juta infeksi setiap tahun. Di Indonesia, penelitian yang dilakukan di 11 rumah sakit di DKI Jakarta pada 2004 menunjukkan bahwa 9,8 persen pasien rawat inap mendapat infeksi yang baru selama dirawat. (http://www.spiritia.or.id/cst/bacacst.php?artno=1043 $\underline{\text { \&menu=perawmenu) }}$
Penelitian ini bertujuan untuk Mendeskripsikan proses pengelolaan linen, Mendeskripsikan desinfeksi yang dilakukan pada proses pengelolaan linen, Mendeskripsikan penggunaan APD pada pekerja dan Mengetahui angka kuman spora spesies Bacilus pada linen sebelum dan sesudah melalui proses pengelolaan linen di Rumah Sakit PKU Muhammadiyah Gombong.

\section{BAHAN DAN METODE}

Metode penelitian : Penelitian ini dilakukan dengan menggunakan metode deskriptif dengan tujuan untuk memperoleh gambaran tentang sanitasi pengelolaan linen di Rumah Sakit PKU Muhammadiyah Gombong.

Penelitian ini akan mengetahui mengenai proses pengelolaan linen, desinfeksi linen, penggunaan APD pada pekerja dan kualitas linen dengan menghitung jumlah angka kuman spora spesies Bacillus pada linen sebelum dan sesudah melalui proses pengelolaan linen. Pengambilan sampel pada linen dilakukan dengan cara usap linen yang bekerja sama dengan Laboratorium Fakultass Biologi Unsoed. Pengukuran dilakukan sebanyak empat sampel antara ruang IBS dan ruang rawat inap.

\section{III.HASIL DAN PEMBAHASAN}

Sejarah singkat pendirian Balai Pengobatan Muhammadiyah Gombong pada Rumah Sakit PKU Muhammadiyah Gombong, Kebumen adalah Rumah Sakit dengan pelayanan pasien 24 jam dengan jenis pelayanan Rawat Inap, Rawat Jalan, Fasilitas Pelayanan Umum (Masjid, ATM, Warseda), Billing system, Pemulasan Jenasah, Home care, Ambulan Gawat Darurat dan telah melakukan MoU Pelayanan dengan pihak kesehatan yaitu : PT Askes, Jamkesmas, Jamsostek, Jasa Raharja, Asuransi Tafakul, DSM, PT KAI, Allianz, PLN dan Telkom.

Hasil pengamatan menggunakan checklist, proses pengelolaan linen di RS PKU Muhammadiyah Gombong memiliki nilai 69,61 \% termasuk dalam kategori memenuhi syarat adapun beberapa item penilaian proses pengelolaan linen antara lain :

a. Pengumpulan

Linen kotor pada setiap ruangan dikumpulkan menggunakan dua ember yang tidak memiliki tutup, terpisah antara linen infeksius dan non infeksius diberi tanda khusus berupa warna ember linen infeksius berwarna merah dan non infeksius berwarna hitam.

Petugas ruangan telah meletakkan linen infeksius dan non infeksius pada wadah yang berbeda. Berdasarkan checklist, nilai untuk tahap pengumpulan linen kotor adalah 100 \% termasuk dalam kategori memenuhi syarat.

b. Pengangkutan

Linen kotor diambil pada jam 07.00 WIB setiap hari menggunakan troli besi yang tidak memiliki wadah khusus antara linen infeksius dan 
non infeksius dan troli pengangkutan linen kotor tidak memiliki tutup.

Saat pengangkutan, linen dicatat jumlah dan nama linen oleh petugas dengan cara mengeluarkan linen kotor dari ember kedalam plastik sebelum diletakkan di troli dengan menghitung jumlah dan nama linen kotor.

Alat pelindung diri yang digunakan hanya masker. Berdasarkan checklist, nilai untuk tahap pengangkutan linen kotor adalah $40 \%$ termasuk dalam kategori tidak memenuhi syarat.

c. Penerimaan

Linen yang terkumpul langsung masuk ke dalam ruangan pencucian linen tidak dilakukan penimbangan terlebih dahulu. Sebelum melakukan proses pencucian, petugas melakukan pemilahan berdasarkan tingkat kekotoran linen seperti linen yang terkena darah, feses, muntahan dan dahak pasien dipisahkan dengan linen kotor yang biasa. Dari hasil pengamatan yang dilakukan menggunakan checklist, nilai untuk penerimaan adalah 50 \% termasuk dalam kategori tidak memenuhi syarat.

d. Pencucian

Proses awal pencucian dilakukan dengan merendam linen infeksius sedangkan linen non infeksius langsung di masukan kedalam mesin pencuci. Petugas memberikan larutan desinfeksi yaitu steriling $S A$ pada bak perendaman dengan menakar kebutuhan larutan desinfeksi yang digunakan yaitu 1 liter larutan steriling SA di campur dengan 100 liter air bersih untuk 25 kg linen. Linen yang terkena noda darah, feses, muntahan dan dahak pasien dibersihkan terlebih dahulu dengan cara disikat dengan menggunakan sando dan di rendam terpisah menggunakan ember plastik, proses perendaman di bak dilakukan selama 15 menit, rendaman di ember plastik kemudian dicuci dengan cara di sikat.

Pembilasan dilakukan dengan cara memindahkan linen yang telah disikat terhadap bak lain dan terus mengaliri bak dengan air mengalir serta membolak balik linen pada bak rendaman dengan tangan. Setelah pembilasan, linen di pindahkan ke dalam ember sebelum dimasukkan mesin cuci untuk di tambahkan pewangi kemudian dikeringkan.

Alat pelindung diri yang digunakan petugas pada proses pencucian hanya memakai masker, sarung tangan, sepatu bot, dan apron tanpa dilengkapi baju kerja khusus, dan penutup kepala. Berdasarkan pengamatan yang dilakukan menggunakan checklist, nilai untuk pencucian linen kotor adalah $85 \%$ termasuk dalam kategori memenuhi syarat.

\section{e. Pengeringan}

Pengeringan linen dilakukan dengan menggunakan dua cara yaitu menggunakan mesin pengering dan diteruskan menggunakan cahaya matahari. Mesin pengering yang digunakan berjumlah dua buah dengan dua buah mesin cuci pengering biasa linen dkeringkan selama 25 menit.

Linen seperti apron dikeringkan menggunakan sinar matahari selama 4 jam sedangkan linen yang lain langsung di setrika. Petugas penjemur hanya memakai masker dan sarung tangan tanpa menggunakan penutup kepala dan baju kerja khusus. Berdasarkan hasil observasi menggunakan checklist didapatkan nilai 85 \% termasuk dalam kategori memenuhi syarat.

f. Penyetrikaan

Linen bersih yang sudah kering kemudian di setrika menggunakan setrika manual karena mesin setrika rol dengan suhu $120^{\circ} \mathrm{C}$ rusak. alat pelindung diri yang dikenakan pekerja hanya memakai masker dan baju kerja khusus tidak menggunakan sarung tangan dan penutup kepala. Berdasarkan checklist, nilai untuk penyetrikaan linen adalah $65 \%$ termasuk kategori memenuhi syarat.

g. Penyimpanan linen bersih

Linen yang sudah disetrika kemudian di masukkan kedalam lemari kayu sesuai nama linen dan ruangan atau bangsal dan sebagian linen langsung di kirim ke ruangan masing-masing yang telah di bungkus plastik. Linen bersih yang berada diruangan disimpan pada lemari kayu dan ditumpuk berdasarkan jenis linen yang sama.

Lemari kayu penyimpanan linen bersih diruangan hanya diberi alas kertas Koran yang sudah tidak terpakai, lemari melebihi kapasitas linen yang disimpan mengakibatkan linen disimpan di meja atau lantai ruang penyimpanan linen.

Penataan tumpukan linen yang baru dicuci ditumpuk dibagian atas, sehingga linen lama yang berada dibawah tetap berada ditumpukan bawah. Berdasarkan checklist, nilai untuk tahap penyimpanan linen adalah $100 \%$ termasuk dalam kategori memenuhi syarat.

h. Pengangkutan linen bersih

Linen di angkut ke masing - masing ruangan oleh petugas menggunakan troli tertutup khusus untuk pengangkutan linen bersih. Troli khusus pengangkutan terbuat dari besi dan didalamnya diberi lapisan kain kulit. Berdasarkan checklist, nilai untuk tahap pengangkutan linen bersih adalah 50 \% termasuk kategori tidak memenuhi syarat.

Desinfeksi linen dilakukan menggunakan larutan steriling $S A$ yang telah dilakukan pengenceran yaitu 1 liter steriling $S A$ dicampur dengan 100 liter air bersih untuk 25 kg linen kemudian di rendam selama 15 menit. Linen yang telah di rendam akan langsung disikat menggunakan sando untuk menghilangkan noda yang terdapat pada linen.

Tersedia alat pelindung diri tetapi belum lengkap, hanya tersedia sepatu but, clemek, 
masker, dan sarung tangan. Tidak tersedia seragam kerja khusus dan penutup kepala. Sehingga perlu dilakukan peningkatan kesadaran terhadap tenaga pengelola linen tentang pentingnya penggunaan APD untuk mencegah terjadinya penyakit akibat kerja karena tenaga yang menangani linen kotor selalu kontak dengan bahan kimia dan menghirup udara yang tercemar oleh kuman pathogen. Untuk mengatasi masalah tersebut dengan memberikan penyuluhan terhadap tenaga pengelola linen secara berkala.

Hasil kualitas linen pada sprei kotor ruang rawat inap (sampel 1), sprei kotor ruang IBS (sampel 2), sprei bersih ruang rawat inap (sampel 3), dan sprei bersih ruang IBS (sampel 4) melalui pemeriksaan angka bakteri Bacillus sp. yang dilakukan di laboratorium mikrobiologi Fakultas Biologi Unsoed pada linen yang telah dicuci adalah :

Tabel Hasil Pemeriksaan Angka Bakteri Bacillus sp. pada Linen

\begin{tabular}{ccc}
\hline Kode & \multicolumn{2}{c}{ Jumlah Bakteri pada media NA } \\
\cline { 2 - 3 } Sampel & CFU / cm $^{2}$ & CFU / inc \\
\hline 1 & 1160 & 7482 \\
\hline 2 & 0 & 0 \\
\hline 3 & 342 & 2205,9 \\
\hline 4 & 0 & 0 \\
\hline
\end{tabular}

Sumber : Hasil Pemeriksaan Angka Bakteri Bacillus sp. Laboratorium Mikrobiologi Fakultas Biologi Unsoed

Keterangan :

Sampel 1 : Linen kotor ruang rawat inap

Sampel 2 : Linen kotor ruang IBS

Sampel 3 : Linen bersih ruang rawat inap

Sampel 4 : Linen bersih ruang IBS

Berdasarkan hasil pemeriksaan di atas, dari ke dua sampel linen bersih yaitu sampel 3 dan 4 yang telah di periksa jumlah spora Bacillus sp. masih dibawah standar.

\section{IV.KESIMPULAN}

\section{Kesimpulan}

Berdasarkan dari hasil penelitian dan pembahasan yang telah diuraikan penulis dapat menyimpulkan bahwa sanitasi pengelolaan linen di Rumah Sakit PKU Muhammadiyah Gombong Kebumen termasuk dalam kategori memenuhi syarat (69,61\%).

Proses pengelolaan linen meliputi pengumpulan, pengangkutan linen kotor, penerimaan linen kotor, pencucian, pengeringan, penyetrikaan, penyimpanan linen bersih dan pengangkutan linen bersih.

Peralatan pengelolaan linen yang digunakan yaitu mesin cuci, mesin pengering, mesin setrika rol, setrika manual, ember, timbangan, kereta dorong, sikat dan bahan yang digunakan berupa detergen bubuk, sabun sereh (sando), bleaching atau cairan pemutih dan pewangi pakaian (softy).
Desinfeksi yang dilakukan di pengelolaan linen Rumah Sakit PKU Muhammadiyah Gombong Kebumen menggunakan larutan steriling $S A$ yang diencerkan terlebih dahulu dengan perbandingan 1 liter steriling SA dicampur dengan 100 liter air bersih untuk $25 \mathrm{~kg}$ linen yang akan dicuci dan di rendam selama 15 menit untuk linen infeksius.

Hasil pengamatan alat pelindung diri yang digunakan pada petugas pengelola linen meliputi masker, sarung tangan, sepatu boot, apron dan pakaian kerja khusus.

Hasil pemeriksaan mikrobiologi spora spesies Bacillus sp. pada linen kotor dan bersih setelah dilakukan pengelolaan di dapatkan hasil yaitu pada linen kotor ruang rawat inap (7482 CFU/inc ${ }^{2}$ ), linen kotor ruang IBS (0 CFU/inc ${ }^{2}$ ), linen bersih ruang rawat inap (2205,9 CFU/inc $\left.{ }^{2}\right)$ dan linen bersih ruang IBS (0 CFU/inc ${ }^{2}$ ) sehingga angka spora spesies Bacillus sp. masih dibawah standar yang ditetapkan Kepmenkes Republik Indonesia nomor 1204/MENKES/SK/X/2004 sebesar $6 \times 10^{3}$ per inc persegi.

Saran

Peneliti menyarankan untuk dilakukan penelitian selanjutnya dengan menggunakan metode lain tentang penelitian studi sanitasi pengelolaan linen di rumah sakit.

\section{DAFTAR PUSTAKA}

Alfian Mubarak, 2014, Studi Sanitasi Pengelolaan Linen di Rumah Sakit Umum Daerah Hj. Anna Lasmanah Banjarnegara Tahun 2014, KTI, Purwokerto : Kementerian Kesehatan RI Politeknik Kesehatan Semarang Jurusan Kesehatan Lingkungan Purwokerto.

Brunner \& Suddarth, 2002, Buku Ajar Keperawatan Medikal Bedah, EGC, Jakarta.

Depkes, 2001, Pedoman Pengendalian Infeksi Nosokomial Di Rumah Sakit, Jakarta.

Depkes, 2003, Pedoman Pelaksanaan Kewaspadaan Universal di Pelayanan Kesehatan, Jakarta.

Depkes, 2009. Undang-Undang Kes. RI No. 36 Tahun 2009 Tentang Kesehatan, Jakarta; Departemen Kesehatan.

http://eprints.undip.ac.id/6476/1/Manajemen_Linen_ Rumah_Sakit_-_Bambang_Shofari.pdf diakses 15 Desember 2014 pukul 20.01 WIB.

http://www.academia.edu/9705763/Pedoman_Manaje rnen_di_Rumah_Sakit_Linen diakses 28 Juli 2015 pukul 15.40 WIB. 
http://www.depkes.go.id/article/view/13010100001/p rofil-visi-dan-misi.html diakses pada 15 Desember 2014 pukul 20.30 WIB.

http://www.spiritia.or.id/cst/bacacst.php?artno=1043 \&menu=perawmenu diakses pada 1 Agustus 2015 pukull 15.00 WIB

Indonesia, Dirjen PPM dan PLP, 1994. Pedoman Sanitasi Rumah Sakit di Rumah Sakit, Departemen Kesehatan RI. Jakarta.

Kepmenkes RI No. 1204/MENKES/SK/X/2004 Tentang Persyaratan Kesehatan Lingkungan Rumah Sakit.
Sapta Raharsa, 1997. Manajemen linen dan Laundry di Rumah Sakit, Pokja Kajian Pelayanan Kesehatan, Pusat Penelitian Kesehatan Universitas Indonesia Jakarta.

Wiwit Saputri, 2012, Studi Sanitasi Pengelolaan Linen di Rumah Sakit Umum Daerah DR. Goeteng Taroenadibrata Kabupaten Purbalingga Tahun 2012, KTI, Purwokerto : Kementerian Kesehatan RI Politeknik Kesehatan Semarang Jurusan Kesehatan Lingkungan Purwokerto. 